\title{
Prevention of Tumor Formation in a Mouse Model of Burkitt's Lymphoma by 6 Weeks of Treatment with Anti-c- myc DNA Phosphorothioate
}

\author{
Ye Huang, Ruthanne Snyder, Michael Kligshteyn, \\ and Eric Wickstrom \\ Department of Pharmacology, Thomas Jefferson University, \\ Philadelphia, Pennsylvania, U.S.A.
}

\begin{abstract}
Background: Transgenic mice bearing a murine immunoglobulin enhancer/c-myc fusion transgene (E $\mu-m y c)$ provide a useful model for Burkitt's lymphoma.

Materials and Methods: Groups of $12 \mathrm{E} \mu$-myc mice were treated prophylactically for 6 weeks after weaning with anti-c-myc DNA phosphorothioate $(20 \mathrm{mg} / \mathrm{kg} /$ day $)$, scrambled control DNA, or saline, delivered by microosmotic pumps.

Results: Half of the mice treated with saline or scrambled control DNA displayed palpable tumors by 8-9 weeks after birth, and $95 \%$ of them did so by 16 weeks,
\end{abstract}

but $75 \%$ of the mice treated with antisense DNA were still free of tumors at the age of 26 weeks. Antisense therapy ablated MYC antigen in the spleens of tumorbearing mice. Plasma physiological parameters indicated no acute toxicity.

Conclusions: Long-term tumor resistance after anti-cmyc DNA therapy implies induction of a host response. Prophylactic anti-c-myc DNA therapy might prevent lymphoma in asymptomatic individuals displaying $c-m y c$ translocations.

\section{INTRODUCTION}

Burkitt's lymphoma constitutes the most frequent hematological malignancy of childhood (1). Lymphoma is also a frequent result of human immunodeficiency virus (HIV) infection (1). This malignancy, like all others, results from a multistep process of oncogene activation or suppressor gene inactivation (2). In Burkitt's lymphoma, virtually all cases display translocation of chromosomes 8 and 14, placing the c-myc proto-oncogene from chromosome 8 under the transcriptional control of the immunoglobulin $\mathrm{M}$ heavy chain enhancer from chromosome 14 (3).

To provide an animal model for childhood Burkitt's lymphoma, transgenic mice were created (4) bearing a murine immunoglobulin $M$

Address correspondence and reprint requests to: Eric Wickstrom, Department of Pharmacology, Thomas Jefferson University, Philadelphia, PA 19107-5541, U.S.A.

${ }^{1}$ Present address: American Cyanamid Research Center, Princeton, NJ 08543, U.S.A. enhancer/c-myc fusion transgene $(\mathrm{E} \mu-m y c)$ isolated from a mouse plasmacytoma (5). Mice in these lines, including the $\operatorname{Tg}(\operatorname{IgH}, \mathrm{Myc})$ Bril57 line studied here, develop aggressive multifocal lymphoma/leukemia (4). Tumors are prominent in $95 \%$ of such mice by 16 weeks after birth. It appears that elevated constitutive expression of c-myc mRNA and antigen does not directly induce tumor onset, but establishes a subpopulation of rapidly proliferating, immature $B$ cells which may be transformed into a malignant phenotype by a subsequent oncogene activation (6). These transgenic mice provide a well-characterized animal model for studying the role of c-myc activation in B cell lymphoma.

In mammalian cells, the c-myc oncogene has proved to be a reliable target for antisense DNA inhibition of gene expression (Refs. 7-21 and Y. Shi et al., submitted). The ability of antisense DNA to turn off individual genes at will in growing cells provides a powerful tool for elucidating the role of a particular gene, and for therapeutic 
intervention when that gene is overexpressed or mutated. Antisense DNAs have been applied against a wide variety of target genes, in viral, bacterial, plant, and animal systems, both in whole cells (22) and in animal models (23). It was therefore of interest to determine whether or not antisense DNA therapy could down-regulate c-myc gene expression in an animal model (24). Nuclease-resistant methylphosphonate DNAs were administered to the E $\mu$-myc transgenic mice by tail vein injection, distributed rapidly to the tissues, and showed no sign of degradation. This single treatment, at about $50 \mathrm{mg} / \mathrm{kg}$, significantly decreased MYC p65 expression, measured 3-4 hr after administration (24). Injection of a scrambled sequence, or saline, had no effect. Similarly, inhibition of restenosis has been reported in pigs by a single administration of anti-c-myc DNA phosphorothioates (25). Furthermore, we have observed significant inhibition of tumorigenesis in nude mice by c-Ha-rastransformed cells as a result of pretreatment of the cells with anti-c-Ha-ras DNA (26).

Having seen a decrease in MYC antigen in response to a single administration of anti-c-myc DNA methylphosphonate (24) we hypothesized that prolonged treatment of $\mathrm{E} \mu-m y c$ transgenic mice with anti-c-myc DNA, inhibiting c-myc expression in the target $B$ cells, might preclude overproliferation of these cells, and interdict tumor progression. To test this hypothesis, DNA was administered by micro-osmotic pumps (27) to $\mathrm{E} \mu$-myc mice which were treated continuously for 6 weeks after weaning with DNA phosphorothioates. Mice treated with saline or the scrambled control DNA displayed palpable tumors over the usual time course, but 11 of the 12 mice treated with anti-c-myc DNA were free of tumors at the age of 9 weeks, when antisense therapy ended. Surprisingly, $75 \%$ of the mice treated with antisense DNA were still free of tumors at the age of 26 weeks, implying the establishment of long-term resistance to myc-induced lymphoma.

\section{MATERIALS AND METHODS}

\section{Transgenic Mice}

E $\mu$-myc transgenic mice embryos (4) were the kind gift of Dr. Ralph Brinster. They were rinsed twice over a 24 -hr period to dislodge any adherent virions and were implanted in the uteri of pseudopregnant (C57BL/6J X SJL/J) $\mathrm{F}_{1}$ hybrid fe- male foster mothers under viral-pathogen-free conditions. The heterozygous offspring were screened for presence of a $\Phi \times 174$ marker sequence in the transgene by PCR amplification (28) of DNA from toe cells at birth. The reliability of this routine screening method was confirmed by Southern blot, using the c-myc probe pRyc7.4, the kind gift of Dr. Maria Luisa Veronese (29). The mouse line is maintained by continually backcrossing $\mathrm{E} \mu$-myc positive males with (C57BL/6J X SJL/J)F $F_{1}$ hybrid females; the offspring in each generation are screened by PCR as above. This investigation was carried out in a pathogen-free animal facility accredited by AAAALAC, and was reviewed and monitored by the Institutional Animal Care and Use Committee to make sure that National Institutes of Health guidelines were followed.

\section{Oligodeoxynucleotide Synthesis}

The PCR primers 5'-dGCAACTTCGGGATGAA AATG-3' (forward) and 5'-dCGAAGCGCGCAT AAATTT-3' (reverse) were synthesized as phosphodiesters (30) on an Applied Biosystems 394 DNA synthesizer. The anti-c-myc sequence 5'dCACGTTGAGGGGCAT-3', and the scrambled sequence 5'-dCTGCTGAGAGTCGAG-3', were synthesized as phosphorothioates (31) at a scale of 120 and $200 \mu \mathrm{mol}$, on a Biosearch 8800 DNA synthesizer. Deprotected oligomers were purified by duplicate precipitation with n-butanol (32), then analyzed to verify purity by high-performance liquid chromatography (8), nuclear magnetic resonance spectroscopy (31), and matrix-assisted laser desorption/ionization mass spectroscopy (33). Oligomers were sterilized by passage through sterile $0.2-\mu \mathrm{m}$ pore syringe filter units.

\section{Micropump Administration}

Groups of $12 \mathrm{E} \mu-m y c$ transgenic mice were selected at weaning, 3 weeks after birth, on the criterion of displaying no palpable tumor at that time. Siblings were assigned into all three treatment groups. Micro-osmotic pumps (Alzet 2002, Palo Alto, CA, U.S.A.) containing $200 \mu \mathrm{l}$ of saline, or saline with $5.0 \mathrm{mM}$ scrambled DNA phosphorothioate or anti-c-myc DNA phosphorothioate were implanted subcutaneously on the upper back of each mouse, anesthetized with avertin $(30 \mathrm{mg} / \mathrm{kg})$. Each pump containing DNA therefore dispensed $1.0 \mu \mathrm{mol}$, at $0.5 \mu \mathrm{l} / \mathrm{hr}$, or 2.5 $\mathrm{nmol} / \mathrm{hr}$, over 14 days. The pumps were replaced 
at 5 and 7 weeks after birth. Thus, each mouse received a dose of $3.0 \mu \mathrm{mol}$ of oligomer, or 15 $\mathrm{mg}$, administered continuously at a nearly uniform rate of about $0.36 \mathrm{mg} /$ day over 6 weeks. Since the mass of 3-week-old mice is about $10 \mathrm{~g}$, and the mass of 9-week-old mice is about $30 \mathrm{~g}$, one estimates an initial dose of $36 \mathrm{mg} / \mathrm{kg} /$ day and a final dose of $12 \mathrm{mg} / \mathrm{kg} / \mathrm{day}$, an average dose of about $20 \mathrm{mg} / \mathrm{kg} /$ day, or about $1 \mathrm{mg} / \mathrm{kg} /$ hr. Tumors were detected by palpation twice weekly, and confirmed on autopsy. For protein and mRNA measurement from spleens and lymph node tumors, mice with established tumors were treated as above for one week.

\section{Western Blot Measurement of MYC p65 Antigen}

Total lymphocytes were collected from both spleens and lymph node tumors in cold DPBS buffer by heart puncture immediately after sacrifice (34). Lymphocyte nuclei were isolated (35) and nuclear protein extracts were prepared (18). In order to standardize comparison of bands from neighboring lanes, exactly $10 \mu \mathrm{g}$ of total nuclear protein from each sample, measured with the BCA protein assay Kit (Pierce, Rockford, IL, U.S.A.), were then loaded onto a $4-20 \%$ polyacrylamide gradient gel, electrophoresed, then blotted onto PVDF membrane (Bio-Rad, Hercules, CA, U.S.A.). Coomassie blue staining of a parallel gel indicated constant intensities of prominent nuclear protein bands in each lane. MYC protein was detected by monoclonal mouse anti-myc antibody (Cambridge Research Biochemicals \#OM-1 1-904, Cambridge, MA, U.S.A.) and horseradish peroxidase conjugated antimouse IgG (Sigma \#A2304, Sigma Chemical Co., St. Louis, MO, U.S.A.), followed by chemiluminescence.

\section{Northern Blot Measurement of c-myc mRNA}

Total RNA was extracted from about $0.3 \mathrm{~g}$ of spleens and lymph node tumors from each mouse (36). About $20 \mu \mathrm{g}$ of total RNA from each sample were electrophoresed on a glyoxal/ DMSO gel (37), then blotted onto a nylon membrane and hybridized with two [ $\left.{ }^{33} \mathrm{P}\right] \mathrm{dCTP}$-labeled probes: the c-myc PstI restriction fragment from pRyc7.4 (29) and the pTRI-GAPDH construct (Ambion \#7431, Austin, TX, U.S.A.). c-Myc mRNA level was calculated based on the density ratio of the myc band compared with the corre- sponding GAPDH band, quantitated with a BioImage densitometry system.

\section{Toxicological Analyses}

Mice were treated with phosphorothioate DNA administered by pellet at approximately 30 $\mathrm{mg} / \mathrm{kg} /$ day for 4 weeks, by syringe at approximately $70 \mathrm{mg} / \mathrm{kg} /$ day for 5 weeks, and by micropump at approximately $20 \mathrm{mg} / \mathrm{kg} /$ day, for up to 6 weeks. At the end of each treatment, plasma from each mouse was taken by heart puncture. Some major physiological values, such as AST, ALT, BUN, creatinine, glucose, and blood sodium, were analyzed on a Kodak 700 chemical analyzer (AMI Town and Country Hospital, Tampa, FL, U.S.A.).

\section{Statistical Analyses}

Tumor onset, Western and Northern blot band densities, and plasma physiological values were analyzed by Kruskal-Wallis one-way analysis of variance on ranks, Dunn's pairwise multiple comparison procedure, and Mann-Whitney rank sum test (38) using the program SigmaStat (Jandel Scientific, San Rafael, CA, U.S.A.).

\section{RESULTS}

\section{Tumor Onset}

Over several generations of observing the $\operatorname{Tg}$ (IgH,Myc)Bril57 line (4), we found that the 57 untreated transgene-positive mice displayed palpable tumors as early as 3 weeks of age, and that half of them developed palpable tumors by the age of 8-9 weeks (Fig. 1). Fifty-five (95\%) of them developed tumors within 16 weeks.

\section{Pellet Administration}

Four-week prolonged release pellets (Innovative Research of America, Toledo, OH, U.S.A.) packed with no drug (placebo) or $4 \mu \mathrm{mol}$ of antisense or scrambled phosphorothioate DNAs were implanted under the skin on the upper back of groups of three to five $\mathrm{E} \mu$ - $m y c$ positive mice within 2 weeks after tumor onset. The total amount of DNA in the pellets and the rate of release from each pellet varied widely and unpredictably. Tumor size, body mass, and lymphocyte differentiation of each mouse were analyzed weekly. Significant percentages of immature lymphocytes were not observed in tail blood smears until late in tumor development, after lymphoid tumors were prevalent throughout the body. Mice with disseminated tumors all dis- 


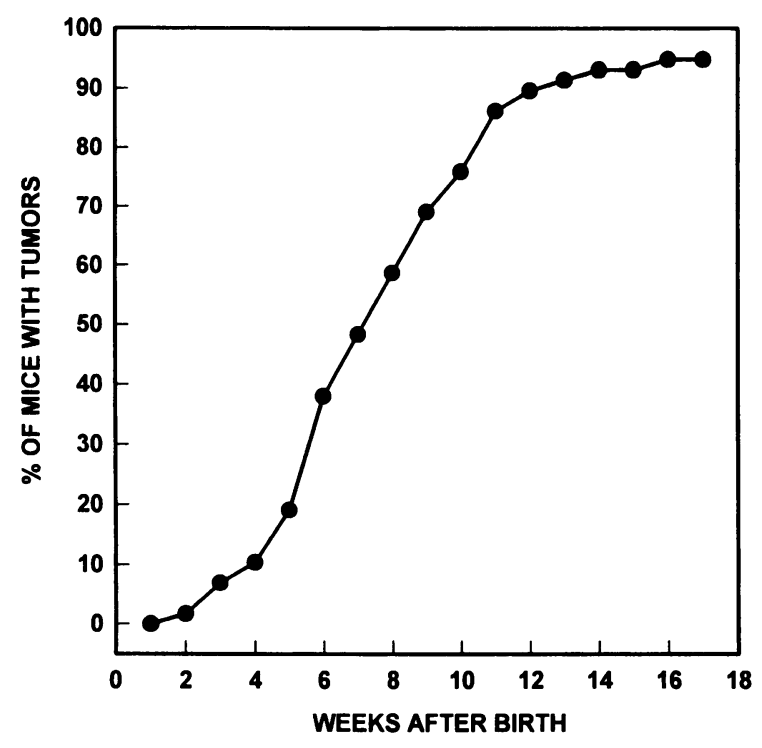

FIG. 1. Time of onset of lymphoid tumors in untreated $\mathrm{E} \mu$-myc transgenic mice from day of birth

Presence of the transgene in these hemizygous mice was detected by PCR analysis of toe tissue at birth. Tumors were detected by palpation twice weekly and confirmed on autopsy. Over several generations, a total of 57 mice were observed.

played blasts and other immature forms, but the extent of peripheral pre-B cell populations common to these mice varied more from mouse to mouse than from treatment group to treatment group. After 4 weeks of treatment, there were no significant differences in changes in tumor size increase or body mass increase among the groups of mice treated with placebo, antisense, or scrambled DNA phosphorothioates (data not shown). Methylphosphonate DNAs were similarly ineffective.

\section{Subcutaneous Administration}

This route was chosen as a simpler and more controllable mode of therapy than pellet implantation. Groups of three to four E $\mu$-myc transgenic mice were selected at weaning, 3 weeks after birth, on the criterion of displaying no palpable tumor at that time. Weaning was the earliest age at which DNA could be administered to mice without danger of maternal rejection. Each mouse received normal saline or saline containing $1.0 \mu \mathrm{mol}$ of antisense or scrambled DNA phosphorothioate under the skin of the back, twice weekly for 5 weeks. At the end of treatment, two out of four mice receiving scrambled
DNA displayed tumors, but none in the antisense group did. In the antisense group, however, epidermal tissues surrounding the site of injection became thick, rigid, and brittle.

\section{Micropump Administration}

This route was substituted for subcutaneous injection in order to avoid epidermal senescence at the site of injection. Three-week-old E $\mu$-myc transgenic mice with no palpable tumors were randomly distributed into groups of 12 . Micropumps dispensing $0.5 \mu \mathrm{l} / \mathrm{hr}$ of antisense or scrambled DNA phosphorothioate $(2.5 \mathrm{nmol} / \mathrm{hr})$, or only saline, for 14 days were implanted, then replaced at 5 and 7 weeks of age. Each mouse received a dose of $3.0 \mu \mathrm{mol}$ of oligomer, or 15 $\mathrm{mg}$, administered continuously at a nearly uniform rate of about $0.36 \mathrm{mg} /$ day over 6 weeks. As the mice grew, the calculated dose decreased from about $36 \mathrm{mg} / \mathrm{kg} /$ day at 3 weeks to about 12 $\mathrm{mg} / \mathrm{kg} /$ day at 9 weeks. The six weeks of therapy represent the longest test of antisense DNA administration in animals to date. During the course of treatment, there were no significant differences in body mass increase or lymphocyte differentiation among the groups of mice treated with either saline, or antisense or scrambled DNA (data not shown).

\section{Tumor Onset}

The mice treated with saline and those treated with the scrambled control DNA displayed tumors over the usual time course (Fig. 2). In the saline group, 5 of 12 mice had palpable tumors by 8 weeks of age, and 9 of 12 had tumors at 15 weeks. In the scrambled group, 5 of 12 mice had tumors by 10 weeks, and 9 of 12 had tumors at 15 weeks. However, in the antisense group only 3 of 12 mice had displayed a tumor by the time of sacrifice at 26 weeks (Fig. 2). One of the three tumors in the antisense group was already palpable 2 weeks after the beginning of the 6 weeks of therapy; perhaps that tumor had already initiated prior to therapy. The second was detected at 15 weeks and the third at 17 weeks. The tumor-free mice treated with antisense DNA were observed up until sacrifice at 48 weeks.

An overall analysis of variance of the tumor data using the nonparametric Kruskal-Wallis procedure $(38)$ indicated significant effects $\left(H_{0}\right.$, $p=0.0000851)$, and this was followed by multiple pairwise comparisons among the groups using Dunn's nonparametric exact test and the 


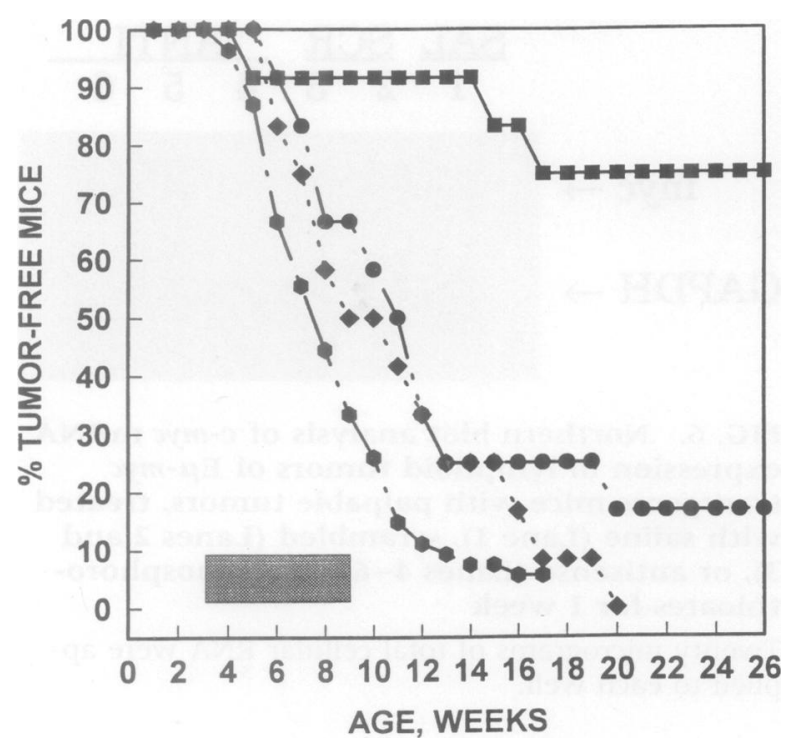

FIG. 2. Age of onset of lymphoid tumors in E $\mu$-myc transgenic mice treated with saline or scrambled or antisense DNA phosphorothioates

Shaded box shows period of continuous administration of DNA from micro-osmotic pumps. no treatment ( 54 mice which were tumor-free at 3 weeks); $\diamond$, saline (12 mice); $\bullet$, scrambled DNA phosphorothioate (12 mice); $\mathbf{0}$, antisense DNA phosphorothioate (12 mice).

Mann-Whitney rank sum test (39). By both tests, the antisense treatment group differed significantly from both the saline $\left(H_{0}, p<0.05\right)$ and scrambled $\left(H_{0}, p<0.05\right)$ groups in tumor onset, while the latter two groups did not differ significantly from each other $\left(H_{0}, p<0.05\right)$. A significant degree of protection by anti-c-myc DNA against tumor onset was therefore observed in this trial, continuing out to 26 weeks of age. This represents the first demonstration of chemoprevention of tumor onset by prophylactic antisense DNA therapy.

\section{Oncogene Expression}

With respect to malignancies dependent upon c-myc expression, it was important to determine whether or not antisense DNA therapy could down-regulate c-myc gene expression in $\mathrm{E} \mu$-myc mice for an extended period. Antigen and messenger measurements, however, were not made on the mice that received long-term therapy from the time of weaning, but on a separate group implanted with micropumps only after tumor onset. In the former group, tumors appeared

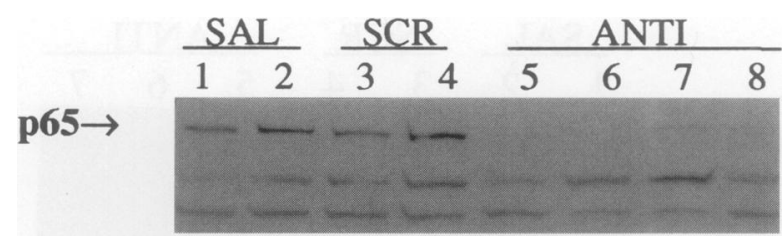

FIG. 3. Western blot analysis of MYC antigen expression in splenic lymphocytes of $\mathrm{E} \mu$-myc transgenic mice with palpable tumors, treated with saline (SAL) (Lanes 1 and 2) or scrambled (SCR) (Lanes 3 and 4), or antisense (ANTI) (Lanes 5-8) DNA phosphorothioates for 1 week

Ten micrograms of nuclear protein extract were applied to each well. Nonspecific lower molecular weight bands arose from secondary antibody.

at arbitrary times in each mouse in each group, and each group included individual mice from different litters born at different times. Thus, it would have been difficult to make comparable protein and RNA measurements after each separate sacrifice of an animal. In the case of antisense DNA treatment, only three mice ever displayed tumors, many weeks apart. In order to maintain the size of the observed cohort, thereby maximizing the statistical reliability of the observations, no mice in the long-term therapy experiment were sacrificed for assay prior to tumor onset.

We wished to determine how effectively antisense DNA inhibited myc gene expression, both in splenic lymphocytes and in tumor cells of the same animal, at the same time in the middle of a pump cycle for all animals examined. c-Myc mRNA is expressed at very low levels in splenic lymphocytes of both normal mice, and $\mathrm{E} \mu-m y c$ transgenic mice prior to tumor establishment. Therefore, these measurements were carried out in a group of eight mice already displaying palpable tumors. Two micropumps were implanted containing saline vehicle, two with scrambled DNA, and four with antisense DNA, at $5.0 \mathrm{mM}$ as above. After 1 week of DNA administration by micropump at about $20 \mathrm{mg} / \mathrm{kg} /$ day, c-myc mRNA and MYC p65 antigen were measured from each mouse. Nuclear proteins and total RNA were collected from both splenic lymphocytes and lymph node tumors. MYC proteins were detected by Western blots and c-myc mRNAs were measured by Northern blots.

MYC protein was virtually undetectable in splenic lymphocytes from all antisense-treated mice (Fig. 3) as it is in normal mice or $\mathrm{E} \mu$-myc 


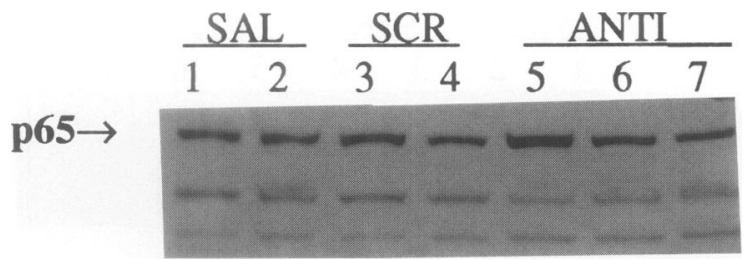

FIG. 4. Western blot analysis of MYC antigen expression in lymphoid tumors of $\mathrm{E} \mu-m y c$ transgenic mice with palpable tumors, treated with saline (SAL) (Lanes 1 and 2) or scrambled (SCR) (Lanes 3 and 4), or antisense (ANTI) (Lanes 5-7) DNA phosphorothioates for 1 week

Ten micrograms of nuclear protein extract were applied to each well.

mice prior to tumor onset, but prominent bands remained in splenic lymphocytes of tumor-bearing mice treated with saline or scrambled DNA (Fig. 3), and in the lymphoid tumors of mice from all treatment groups (Fig. 4). c-Myc mRNA measured in the same animals, however, was not significantly reduced either in splenic lymphocytes of the mice with the antisense treatment (Fig. 5) or in lymphoid tumors as compared with control groups (Fig. 6). The reduction in MYC antigen in the splenic lymphocytes of tumorbearing mice treated with antisense DNA correlates with treatment with antisense DNA therapy, but the tumors themselves were apparently unaffected. However, this observation made it plausible that prophylactic therapy with antisense DNA prior to tumor establishment might slow the proliferation of the transgenic pre-B cell
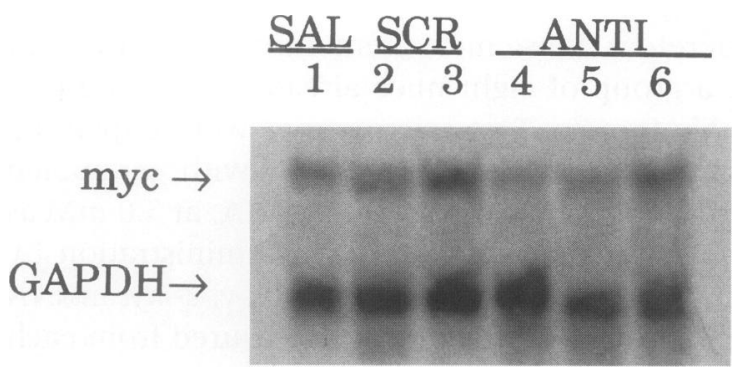

FIG. 5. Northern blot analysis of c-myc mRNA expression in splenic lymphocytes of $\mathrm{E} \mu$-myc transgenic mice with palpable tumors, treated with saline (Lane 1) or scrambled (Lanes 2 and 3) or antisense (Lanes 4-6) DNA phosphorothioates for 1 week

Twenty $\mu \mathrm{g}$ of total cellular RNA were applied to each well.

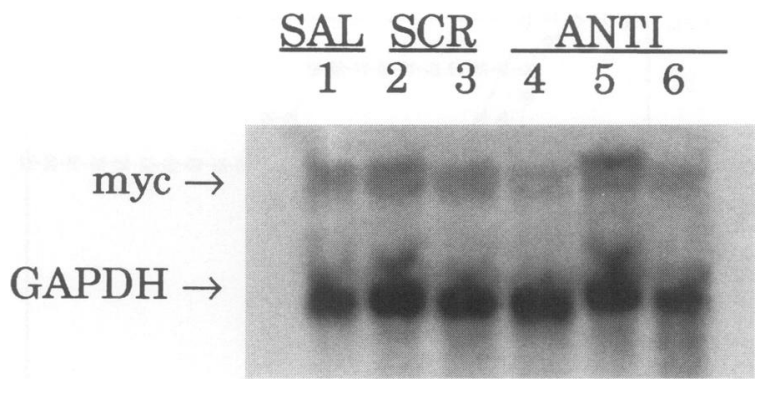

FIG. 6. Northern blot analysis of $c-m y c$ mRNA expression in lymphoid tumors of $\mathrm{E} \mu$-myc transgenic mice with palpable tumors, treated with saline (Lane 1), scrambled (Lanes 2 and 3), or antisense (Lanes 4-6) DNA phosphorothioates for 1 week

Twenty micrograms of total cellular RNA were applied to each well.

population enough to lower the rate of tumor onset in $\mathrm{E} \mu$-myc mice.

\section{Toxicology}

Phosphorothioate DNA has been found to be toxic to liver, kidney, spleen, and some other major organs of mice at intraperitoneal bolus doses above $100 \mathrm{mg} / \mathrm{kg}$, three times per week for 2 weeks. At this dose range, serum aspartate aminotransferase activity doubled or tripled, alanine aminotransferase activity doubled, and glucose levels decreased by $30 \%$. More than 150 $\mathrm{mg} / \mathrm{kg}$ in a single bolus induced acute death in some mice (39). However, among the mice treated with phosphorothioate DNA at the dose rates described in this work, the lack of perturbation of increase in body mass with time provides a general indication of negligible acute toxicity. Furthermore, plasma physiological values were analyzed at the time of sacrifice in normal mice and in transgenic mice that were treated with saline or scrambled or antisense DNA phosphorothioates. In eight mice with established tumors, DNAs were administered by pellet at approximately $30 \mathrm{mg} / \mathrm{kg} /$ day for 4 weeks. In four mice without palpable tumors at 3 weeks, DNAs were administered by subcutaneous injection at approximately $250 \mathrm{mg} / \mathrm{kg}$ twice weekly $(70 \mathrm{mg} /$ $\mathrm{kg} /$ day) for 5 weeks. In four mice without palpable tumors at 3 weeks, DNAs were administered by micropump at $0.36 \mathrm{mg} / \mathrm{day}$, or an average of $20 \mathrm{mg} / \mathrm{kg} /$ day, for 6 weeks, or until establishment of large tumors. In contrast to mice treated with intraperitoneal bolus doses at $100 \mathrm{mg} / \mathrm{kg}$ (39), 
there were no significant differences detected among the three groups in major physiological values such as aspartate aminotransferase (AST), alanine aminotransferase (ALT), creatinine, blood urea nitrogen, glucose and blood sodium, indicating the lack of acute toxicity of phosphorothioate DNA at the therapeutic dose (Table 1).

Splenomegaly has also been reported in mice as a result of phosphorothioate DNA administration (40). This phenomenon was also observed in the $\mathrm{E} \mu$-myc mice treated with antisense or scrambled phosphorothioate DNAs. At an age of 12-16 weeks, the mass of spleens from normal mice averaged $0.1 \mathrm{~g}$, while those from $\mathrm{E} \mu$-myc mice receiving phosphorothioates averaged $0.3 \mathrm{~g}$. However, the spleens of $\mathrm{E} \mu-m y c$ mice treated with the placebo averaged $0.25 \mathrm{~g}$, so that the observed splenomegaly may arise from the stress of bearing tumors and implantation of pellets or micropumps.

Procreation is usually inadvisable during chemotherapy, but three female mice treated with scrambled DNA were mated inadvertently during treatment and gave birth to normal size healthy litters. A male mouse treated with antisense DNA was mated 2 weeks after the end of therapy, and fathered two normal size healthy litters. Hence, there was no apparent acute toxicity to the gonads as a result of phosphorothioate therapy at the therapeutic dose.

\section{DISCUSSION}

When antisense DNA administration by pellet was attempted after tumor onset, autopsies revealed numerous tumors in each of the $\mathrm{E} \mu$-myc mice, disseminated to most of the lymph nodes, in varying sizes up to several grams. Disease progression was not halted in mice treated by pellet with antisense DNA phosphorothioates or methylphosphonates after tumor establishment. However, the lack of measurable regression may only reflect the pellet mode of administration utilized in the first two trials. Pellet administration was discarded following these unpromising results. Inconsistent, poor delivery of antisense DNA may have resulted in a low effective dose, obscuring any antisense effects. Therefore, another hypothesis to be tested holds that continuous administration of antisense DNA over many weeks might be sufficient to reduce the growth of an established tumor. However, it is apparent from Fig. 3 that one week of such therapy failed to depress MYC antigen.
One may then hypothesize that inhibition of c-myc overexpression early in life, prior to secondary neoplastic transformation, might interdict tumor formation. To test this hypothesis, antisense DNA therapy was then initiated at weaning, three weeks of age, the earliest time at which pups could be handled without danger of maternal rejection.

Subcutaneous administration was tested, and none of the mice receiving antisense DNA displayed tumors at the age of 8 weeks, when the 5 weeks of therapy ended. However, the senescence of the skin around the site of injection, in the case of antisense DNA, presented an undesirable side effect. Normally, mature epidermis includes a differentiating compartment and a proliferating compartment. MYC protein is one of the crucial factors regulating keratinocyte growth, differentiation, and apoptosis in the mature epidermis (41). Down-regulation of c-myc expression directly induces terminal differentiation of keratinocytes, and potently initiates apoptosis, as well as inhibiting proliferation. Both lead to keratinocyte cell death. Furthermore, keratinocytes efficiently internalize oligodeoxynucleotides (42). Therefore, we think that the dermal toxicity that occurred in the antisense-treated group was a direct effect of a high local concentration of anti-c-myc DNA.

The subcutaneous trial implied that prolonged and frequent administration of antisense DNA under the skin by syringe would be too toxic to use in a longer, larger trial. Prolonged and frequent intraperitoneal administration seemed too traumatic. Envisioning 6 weeks of therapy, we therefore decided to try antisense DNA therapy by implantation of a series of three 14-day micro-osmotic pumps. Following 1 week of such therapy, MYC antigen was suppressed in the spleens of tumor-bearing mice treated with antisense DNA (Fig. 3), although no significant inhibition was observed in the corresponding lymphoid tumors from the same animals (Fig. 4). Poor penetration by antisense DNA into the tumors from the blood may be one possible explanation for the lack of MYC ablation in the tumors. In neither spleens nor lymphoid tumors was c-myc mRNA reduced (Figs. 4 and 5). Perhaps a transcriptional feedback mechanism replenished c-myc mRNA presumably ablated by RNase $\mathrm{H}$ in the spleens of antisense treated animals. Such a feedback phenomenon has been observed in acute myelogenous leukemia cells treated with antisense DNA against p53, where the antigen level was also depressed, without 
concomitant reduction of the mRNA band on a Northern blot (43).

In the micropump trial, anti-c-myc DNA therapy dramatically inhibited tumor progression when administered prophylactically, before the appearance of palpable tumors. The dose of racemic antisense DNA phosphorothioate administered corresponds to about $20 \mathrm{mg} / \mathrm{kg} /$ day over the 6 weeks of therapy. The rather high dose that allowed chemoprevention may in principle be reduced. Dose-response experiments which are underway should reveal how low a concentration will be effective. However, one may hypothesize that potency could be elevated significantly by use of stereospecific all-Rp phosphorothioate (44) or all-Rp methylphosphonate (45) oligomers, which display much stronger hybridization than the racemic oligomers used above. For prolonged or chronic therapy, intestinal uptake (46) might even allow oral administration.

The question of sequence specificity of antisense DNA inhibition must be addressed, particularly when the antisense sequence includes a $\mathrm{G}_{4}$ segment (47). In the case of anti-c-myc DNA phosphodiesters used to inhibit proliferation of human promyelocytic HL-60 cells (7-14), 10 different sites from the $5^{\prime}$ end to the beginning of the coding domain in the second exon of c-myc mRNA were targeted. All 10 antisense DNAs in- hibited MYC antigen levels between 40 and $90 \%$, under conditions in which our original initiation codon antisense sequence with a $\mathrm{G}_{4}$ segment induced $70 \%$ inhibition. The same sequence failed to inhibit Q8 cells transformed by avian c-myc oncogene, with four mismatches in the antisense target (8). In the case of anti-c-myc DNA phosphorothioates used to inhibit proliferation of smooth muscle cells involved in restenosis (Refs. 17 and 25, and Y. Shi et al., submitted), our original initiation codon antisense sequence with a $\mathrm{G}_{4}$ segment and two other antisense sequences were effective inhibitors, but scrambled, sense, reverse, and 4-nt mismatch controls showed no activity. Recently, anti-c-myb and anti-c-myc DNA phosphorothioates, as well as control sequences, with $G_{4}$ segments were observed to inhibit smooth muscle cell proliferation nonspecifically, when the cells were exposed to $30 \mu \mathrm{M}$ DNA for $24 \mathrm{hr}(48)$. At this toxic dose, however, nonspecific inhibition should be expected (49). In contrast, typical antisense DNA phosphorothioate concentrations of $0.2-2.0 \mu \mathrm{M}$ result in sequence specific effects, as in the other studies mentioned above.

Another possibility for nonspecific effects in vivo arises from the presence of the 5 '-dCACGTT segment of the anti-c-myc DNA, a sequence close to the dRRCGYY consensus which has recently been reported to induce $B$ cell stimulation in

TABLE 1. Major plasma physiological values of E $\mu$-myc transgenic mice treated with DNA phosphorothioates for 4 to 6 weeks at doses up to $70 \mathrm{mg} / \mathrm{kg} / \mathrm{day}$

\begin{tabular}{|c|c|c|c|c|c|c|}
\hline $\begin{array}{l}\text { Treatment } \\
\text { Group }\end{array}$ & $\begin{array}{c}\text { AST } \\
\text { (SGOT) } \\
\text { (IU/l) }\end{array}$ & $\begin{array}{c}\text { ALT } \\
\text { (SGPT) } \\
\text { (IU/l) }\end{array}$ & $\begin{array}{c}\text { Blood Urea } \\
\text { Nitrogen } \\
\text { (mg/dl) }\end{array}$ & $\begin{array}{c}\text { Blood } \\
\text { Creatinine } \\
(\mathbf{m g} / \mathrm{dl})\end{array}$ & $\begin{array}{l}\text { Blood } \\
\text { Glucose } \\
\text { (mg/dl) }\end{array}$ & $\begin{array}{c}\text { Blood } \\
\text { Sodium } \\
(\mathrm{mEq} / \mathrm{dl})\end{array}$ \\
\hline Normal control $^{a}$ & $\begin{array}{c}438 \pm 241 \\
(4)\end{array}$ & $\begin{array}{c}455 \pm 247 \\
(4)\end{array}$ & $\begin{array}{c}28 \pm 14 \\
(4)\end{array}$ & $\begin{array}{c}0.28 \pm 0.15 \\
(4)\end{array}$ & $\begin{array}{c}202 \pm 15 \\
(4)\end{array}$ & $\begin{array}{c}136 \pm 3^{b} \\
(4)\end{array}$ \\
\hline Saline only & $\begin{array}{c}518 \pm 328 \\
(8)\end{array}$ & $\begin{array}{c}131 \pm 120 \\
(8)\end{array}$ & $\begin{array}{c}31 \pm 12 \\
(7)\end{array}$ & $\begin{array}{c}0.29 \pm 0.06 \\
(8)\end{array}$ & $\begin{array}{c}144 \pm 33 \\
\text { (3) }\end{array}$ & $\begin{array}{c}154 \pm 14^{b} \\
(7)\end{array}$ \\
\hline Scrambled & $658 \pm 341$ & $154 \pm 72$ & $35 \pm 14$ & $0.35 \pm 0.10$ & $157 \pm 47$ & $148 \pm 11$ \\
\hline DNA antisense & $\begin{array}{c}(4) \\
627 \pm 306\end{array}$ & $\begin{array}{c}(4) \\
88 \pm 10\end{array}$ & $\begin{array}{c}(4) \\
38 \pm 24\end{array}$ & $\begin{array}{c}(4) \\
0.43 \pm 0.39\end{array}$ & $\begin{array}{c}(2) \\
229 \pm 30\end{array}$ & $\begin{array}{c}(2) \\
145 \pm 0\end{array}$ \\
\hline DNA ANOVA ${ }^{c}$ & $\begin{array}{l}\text { (4) } \\
\text { No }\end{array}$ & $\begin{array}{l}(4) \\
\text { No }\end{array}$ & $\begin{array}{l}(4) \\
\text { No }\end{array}$ & $\begin{array}{l}(4) \\
\text { No }\end{array}$ & $\begin{array}{l}(3) \\
\text { No }\end{array}$ & $\begin{array}{l}(3) \\
\text { Yes }\end{array}$ \\
\hline
\end{tabular}

Numbers in parentheses indicate the number of samples for each measurement.

${ }^{a} \mathrm{E} \mu$-myc negative mice.

${ }^{b}$ Significant difference between these two groups by Dunn's multiple pairwise comparison method.

'Nonparametric comparison among groups by Kruskal-Wallis one-way analysis of variance on ranks. 
mice $24 \mathrm{hr}$ after a bolus of about $25 \mathrm{mg} / \mathrm{kg}$, but not at $5 \mathrm{mg} / \mathrm{kg} \mathrm{(50).} \mathrm{On} \mathrm{the} \mathrm{one} \mathrm{hand,} \mathrm{the} \mathrm{mi-}$ cropump dose rate of $1 \mathrm{mg} / \mathrm{kg} / \mathrm{hr}$ may never achieve a threshold serum level of anti-c-myc DNA that might activate B cells. On the other hand, one may hypothesize that elevated B cell activity in mice over 6 weeks old might contribute to long-term tumor resistance, although no MYC reduction or tumor regression was observed in established tumors (Fig. 4).

In view of the positive results of the micropump trial, one could postulate screening of individuals at risk for c-myc translocation, such as HIV-infected individuals. Although the 8:14 chromosomal translocation is not frequent enough in children to justify screening of a large population, it does occur frequently in HIV-infected individuals, inducing lymphomas (1). Acquired immunodeficiency syndrome (AIDS)-associated non-Hodgkin's lymphomas typically display translocation of c-myc to an immunoglobulin locus $(51,52)$. If c-myc translocation precedes onset of lymphoma by any appreciable time, then screening might reveal positive evidence of c-myc activation prior to malignancy. Individuals displaying c-myc translocation could then be treated with antisense DNA to interdict tumor onset. It may therefore be reasonable to propose prophylactic anti-c-myc DNA therapy for HIVinfected individuals who display c-myc translocation in peripheral B cells. Would one not, however, expect to find systemic toxicity upon antisense inhibition of c-myc expression in proliferating cells? Fortunately for this prophylactic model, it has been observed in mice that DNA phosphorothioates are preferentially taken up by B cells, particularly when stimulated by a B cell mitogen (53), which may now be said to include the 5'-dCACGTT segment of the anti-c-myc DNA itself (50). Finally, the down-regulation of MYC protein observed in splenic lymphocytes (Fig. 3) suggests that anti-c-myc therapy might prove beneficial in those hematological malignancies in which cellular proliferation depends upon elevated c-myc expression.

Another significant question to be addressed concerns the extended tumor-free survival of 9 of the 12 antisense treated mice in the fourth trial (Fig. 2). The original hypothesis predicted postponement of tumorigenesis during the course of antisense therapy (i.e., until the end of the sixth week of DNA administration, 9 weeks of age) but not long-term resistance. What mechanism could one then postulate to explain the phenomenon? In the case of $\mathrm{E} \mu-m y c$ mice, it may be that antisense inhibition of the expanded pre-B cell population limited the opportunities for establishment of tumor clones until the animals were sufficiently mature to eliminate transformed cells by normal immunological processes. In that case, 2 or 4 weeks of antisense therapy, up to an age of 7 weeks, might be insufficient to allow long-term resistance. Alternatively, up-regulation of c-myc expression at the end of therapy in transformed cells may have driven them into apoptosis, as with promyelocytic HL-60 cells (21). It is also possible that antisense inhibition induced sufficient differentiation of c$m y c$ transformed cells $(11,14)$ to expose them to immune surveillance and specific $\mathrm{T}$ cell activation. Bystander effects have been observed in other forms of genetic therapy $(54,55)$, including antisense therapy $(56,57)$. It will be of great interest to examine and test the hypothetical forms of immunological activation set in motion by antisense DNA therapy.

\section{ACKNOWLEDGMENTS}

We thank Dr. Gary Gray for valuable discussions and assistance with the statistical analyses; Dr. Gary Lyman and Dr. Paul Greenlee for analysis of lymphocyte differentiation; and Dr. Gray, Dr. Arthur Buchberg, and Dr. Bruno Calabretta for critical reading of the manuscript. We are most grateful to Dr. Eric P. Sandgren, Dr. Ralph L. Brinster, and Dr. Richard D. Palmiter for their gift of fertilized embryos of the E $\mu$-myc transgenic mouse line; to Dr. Jaspal Khillan and Dr. Tim Manser for their help in establishing the line in our pathogen-free animal facility; and to Dr. Maria Luisa Veronese for a sample of pRyc7.4. This work was supported by a National Institutes of Health (NIH) training grant fellowship to $\mathrm{YH}$ and NIH Grant CA42960 to EW.

\section{REFERENCES}

1. Magrath I. (1990) The pathogenesis of Burkitt's lymphoma. Adv. Cancer Res. 55: 133270.

2. Bishop JM. (1991) Molecular themes in oncogenesis. Cell 64: 235-248.

3. de The G. (1993) The etiology of Burkitt's lymphoma and the history of the shaken dogmas. Blood Cells 19: 667-673.

4. Adams JM, Harris AW, Pinkert CA, et al. (1985) The c-myc oncogene driven by immunoglobulin enhancers induces lymphoid ma- 
lignancy in transgenic mice. Nature 318: 533-538.

5. Corcoran LM, Cory S, Adams JM. (1985) Transposition of the immunoglobulin heavy chain enhancer to the myc oncogene in a murine plasmacytoma. Cell 40: 71-79.

6. Harris AW, Pinkert CA, Crawford M, Langdon WY, Brinster RL, Adams JM. (1988) The $\mathrm{E} \mu$-myc transgenic mouse: a model for highincidence spontaneous lymphoma and leukemia of early B cells. J. Exp. Med. 167: 353371.

7. Heikkila R, Schwab G, Wickstrom E, et al. (1987) A c-myc antisense oligodeoxynucleotide inhibits entry into $S$ phase but not progress from G0 to Gl. Nature 328: 445-449.

8. Wickstrom EL, Bacon TA, Gonzalez A, Freeman DL, Lyman GH, Wickstrom E. (1988) Human promyelocytic leukemia HL-60 cell proliferation and c-myc protein expression are inhibited by an antisense pentadecadeoxynucleotide targeted against c-myc mRNA. Proc. Natl. Acad. Sci. U.S.A. 85: 10281032.

9. Holt JT, Redner RL, Nienhuis AW. (1988) An oligomer complementary to c-myc mRNA inhibits proliferation of HL-60 promyelocytic cells and induces differentiation. Mol. Cell. Biol. 8: 963-973.

10. Haral-Bellan A, Ferris DK, Vinocour M, Holt JT, Farrar WL. (1988) Specific inhibition of c-myc protein biosynthesis using an antisense synthetic deoxyoligonucleotide in human T lymphocytes. J. Immunol. 140: 24312435.

11. Wickstrom EL, Bacon TA, Gonzalez A, Lyman GH, Wickstrom E. (1989) Anti-c-myc DNA oligomers increase differentiation and decrease colony formation by HL-60 cells. In Vitro Cell. Dev. Biol. 25: 297-302.

12. McManaway ME, Neckers LM, Loke SL, et al. (1990) Tumour-specific inhibition of lymphoma growth by an antisense oligodeoxynucleotide. Lancet 335: 808-811.

13. Bacon TA, Wickstrom E. (1991) Walking along human c-myc mRNA with antisense oligonucleotides: Maximum efficacy at the 5' cap region. Oncogene Res. 6: 13-19.

14. Bacon TA, Wickstrom E. (1991) Daily addition of an anti-c-myc DNA oligomer induces granulocytic differentiation of human promyelocytic leukemia HL-60 cells in both serum-containing and serum-free media. Oncogene Res. 6: 21-32.

15. Watson PH, Pon RT, Shiu RPC. (1991) Inhi- bition of c-myc expression by phosphorothioate antisense oligonucleotide identifies a critical role for c-myc in the growth of human breast cancer. Cancer Res. 51: 3996-4000.

16. Paria BC, Dey SK, Andrews GK. (1992) Antisense c-myc effects on preimplantation mouse embryo development. Proc. Natl. Acad. Sci. U.S.A. 89: 10051-10055.

17. Shi Y, Hutchinson HG, Hall DJ, Zalewski A. (1993) Down regulation of c-myc expression by antisense oligonucleotides inhibits proliferation of human smooth muscle cells. Circulation 88: 1190-1195.

18. Biro S, Fu Y-M, Yu Z-X, Epstein SE. (1993) Inhibitory effects of antisense oligodeoxynucleotides targeting c-myc mRNA on smooth muscle cell proliferation and migration. Proc. Natl. Acad. Sci. U.S.A. 90: 654-658.

19. Peña A, Reddy CD, Wu S, et al. (1993) Regulation of human ornithine decarboxylase expression by the c-Myc-Max protein complex. J. Biol. Chem. 268: 27277-27285.

20. Cherney BW, Bhatia K, Tosato G. (1994) A role for deregulated c-Myc expression in apoptosis of Epstein-Barr virus-immortalized B cells. Proc. Natl. Acad. Sci. U.S.A. 91: 1296712971.

21. Kimura S, Maekawa T, Hirakawa $\mathrm{K}, \mathrm{Mu}-$ rakami A, Abe T. (1995) Alterations of c-myc expression by antisense oligodeoxynucleotides enhance the induction of apoptosis in HL-60 cells. Cancer Res. 55: 1379-1384.

22. Wickstrom E (ed). (1991) Prospects for Antisense Nucleic Acid Therapy of Cancer and AIDS. Wiley-Liss, New York.

23. Agrawal S (ed). (1995) Oligonucleotide Therapeutic Approach: Near Clinical Development. Humana Press, New York.

24. Wickstrom E, Bacon TA, Wickstrom EL. (1992) Down-regulation of c-myc antigen expression in lymphocytes of $\mathrm{E} \mu-m y c$ transgenic mice treated with anti-c-myc DNA methylphosphonate. Cancer Res. 52: 67416745.

25. Shi Y, Fard A, Galeo A, et al. (1994) Transcatheter delivery of c-myc antisense oligomers reduces neointimal formation in a porcine model of coronary artery balloon injury. Circulation 90: 944-951.

26. Gray G, Hebel D, Hernandez O, Pow-Sang JM, Wickstrom E. (1993) Antisense DNA Inhibition of tumor growth by $\mathrm{T} 24 \mathrm{c}-\mathrm{Ha}$-rastransformed NIH3T3 Cells in athymic nude mice. Cancer Res. 53: 577-580. 
27. Ratajczak MZ, Kant JA, Luger SM, et al. (1992) In vivo treatment of human leukemia in a scid mouse model with c-myb antisense oligodeoxynucleotides. Proc. Natl. Acad. Sci. U.S.A. 89: 1 1823-1 1827.

28. Arita M, Li S-W, Bertolette DC, Khillan JS. (1995) Quick screening of newborn transgenic mouse pups by polymerase chain reaction (PCR). Intl. J. Anim. Sci. 10: (In press).

29. Sun LK, Showe LC, Croce CM. (1986) Analysis of the $3^{\prime}$ flanking region of the human c-myc gene in lymphomas with the $t(8 ; 22)$ and $\mathrm{t}(2 ; 8)$ chromosomal translocations. $\mathrm{Nu}$ cleic Acids Res. 14: 4037-4050.

30. Sinha ND, Biernat J, McManus J, Köster H. (1984) Polymer support oligonucleotide synthesis XVIII: Use of $\beta$-cyanoethyl-N,Ndialkylamino-/N-morpholino phosphoramidite of deoxynucleosides for the synthesis of DNA fragments simplifying deprotection and isolation of the final product. Nucleic Acids Res. 11: 4539-4557.

31. Iyer RP, Phillips LR, Egan W, Regan JB, Beaucage SL. (1990) The automated synthesis of sulfur-containing oligodeoxyribonucleotides using 3H-1,2-benzodithiol-3one 1,1-dioxide as a sulfur-transfer reagent. J. Org. Chem. 55: 4693-4699.

32. Sawadogo M, Van Dyke MW. (1991) A rapid method for the purification of deprotected oligodeoxynucleotides. Nucleic Acids Res. 19: 674.

33. Pieles U, Zürcher $W$, Schär $M$, Moser HE. (1993) Matrix-assisted laser desorption ionization time-of-flight mass spectrometry: a powerful tool for the mass and sequence analysis of natural and modified oligonucleotides. Nucleic Acids Res. 21: 3191-3196.

34. Mishell BB, Shiigi SM, Henry C, et al. (1980) Preparation of mouse cell suspensions. In: Mishell BB, Shiigi SM (eds). Selected Methods in Cellular Immunology. W. H. Freeman, San Francisco, pp. 3-5.

35. Klempnauer KH, Sippel AE. (1986) Subnuclear localization of proteins encoded by the oncogene $\mathrm{v}-m y b$ and its cellular homolog c-myb. Mol. Cell. Biol. 6: 62-69.

36. Chomczynski P, Sacchi N. (1987) Single-step method of RNA isolation by acid guanidinium thiocyanate-phenol-chloroform extraction. Anal. Biochem. 162: 156-159.

37. Sambrook J, Fritsch EF, Maniatis T. (1989) Molecular Cloning-A Laboratory Manual. 2nd Ed., Cold Spring Harbor Laboratory Press, Cold Spring Harbor, NY, pp. 7.40-7.42.
38. Siegel S. (1956) Nonparametric Statistics for the Behaviorial Sciences. McGraw-Hill, New York.

39. Sarmiento AM, Perez JR, Becker JM, Narayanan R. (1994) In vivo toxicological effects of rel A antisense phosphorothioates in CD-1 mice. Antisense Res. Dev. 4: 99-107.

40. Branda RF, Moore AL, Mathews L, McCormack JJ, Zon G. (1993) Immune cell stimulation by antisense oligodeoxynucleotide phosphorothioates complementary to the rev gene of HIV-1. Biochem. Pharmacol. 45: 20372043.

41. Polakowska RR, Haake AR. (1994) Apoptosis: The skin from a new perspective. Cell Death Different. 1: 19-31.

42. Noonberg SB, Garovoy MR, Hunt CA. (1993) Characteristics of oligonucleotide uptake in human keratinocyte cultures. J. Invest. Dermatol. 101: 727-731.

43. Bayever E, Haines KM, Copple BL, Joshi SS, Iversen PL. (1995) Interactions between antisense oligonucleotides to p53 mRNA and reactive oxygen in acute myelogenous leukemia. Proc. Am. Assoc. Cancer Res. 36: 411.

44. Stec WJ, Grajkowski A, Koziolkiewicz M, Uznanski B. (1991) Novel route to oligo(deoxynucleoside phosphorothioates). Stereocontrolled synthesis of P-chiral oligo(deoxynucleoside phosphorothioates). Nucleic Acids Res. 19: 5883-5888.

45. Vyazovkina EV, Savchenko EV, Lokhov SG, Engels JW, Wickstrom E, Lebedev AV. (1994) Synthesis of specific diastereomers of a DNA methylphosphonate heptamer, $\mathrm{d}(\mathrm{C} p \mathrm{C} p \mathrm{~A} p \mathrm{~A} p$ $\mathrm{A} p \mathrm{C} p \mathrm{~A})$, and stability of base pairing with the normal DNA octamer d(TpGpTpTpTpGpGpC). Nucleic Acids Res. 22: 2404-2409.

46. Hughes JA, Avrutskaya AV, Brouwer K, Wickstrom E, Juliano RL. (1995) Radiolabeling of methylphosphonate and phosphorothioate oligonucleotides and evaluation of their transport in everted rat jejunum sacs. Pharmacol. Res. 12: 817-824.

47. Yaswen P, Stampfer MR, Ghosh K, Cohen JS. (1993) Effects of sequence of thioated oligonucleotides on cultured human mammary epithelial cells. Antisense Res. Dev. 3: 67-77.

48. Burgess TL, Fisher EF, Ross SL, et al. (1993) The antiproliferative activity of $c-m y b$ and $c-m y c$ antisense oligonucleotides in smooth muscle cells is caused by a nonantisense mechanism. Proc. Natl. Acad. Sci. U.S.A. 92: 4051-4055.

49. Ho PTC, Ishiguro K, Wickstrom E, Sartorelli 
AC. (1991) Non-sequence-specific inhibition of transferrin receptor expression in HL-60 leukemia cells by phosphorothioate antisense oligodeoxynucleotides. Antisense Res. Dev. 1: 329-342.

50. Krieg AM, Yi A-Y, Matson S, et al. (1995) CpG motifs in bacterial DNA trigger direct B-cell activation. Nature 374: 546-549.

51. Gaidano G, Parsa NZ, Tassi V, et al. (1993) In vitro establishment of AIDS-related lymphoma cell lines: Phenotypic characterization, oncogene and tumor suppressor gene lesions, and heterogeneity in Epstein-Barr virus infection. Leukemia 7: 1621-1629.

52. Prevot S, Raphael M, Fournier JG, Diebold J. (1993) Detection by in situ hybridization of HIV and c-myc RNA in tumour cells of AIDSrelated B-cell lymphomas. Histopathology 22: 151-156.

53. Iversen PL, Crouse D, Zon G, Perry G. (1992) Binding of antisense phosphorothioate oligonucleotides to murine lymphocytes is lin- eage specific and inducible. Antisense Res. Dev. 2: 223-233.

54. Vile RG, Nelson JA, Castleden S, Chong H, Hart R. (1994) Systemic gene therapy of murine melanoma using tissue specific expression of the HSVtk gene involves an immune component. Cancer Res. 54: 6228-6234.

55. Townsend SE, Su FW, Atherton JM, Allison JP. (1994) Specificity and longevity of antitumor immune responses induced by B7-transfected tumors. Cancer Res. 54: 6477-6483.

56. Trojan J, Johnson TR, Rudin SD, Ilan J, Tykocinski ML, Ilan J. (1993) Treatment and prevention of rat glioblastoma by immunogenic C6 cells expressing antisense insulinlike growth factor 1 RNA. Science 259: 94-97.

57. Resnicoff M, Sell C, Rubini M, et al. (1994) Rat glioblastoma cells expressing an antisense RNA to the insulin-like growth factor I (IGF-I) receptor are non-tumorigenic and induce regression of wild-type tumors. Cancer Res. 54: 2218-2222. 